\title{
Screening Soils for Suppressiveness to Rhizoctonia solani and Pythium splendens*
}

\author{
Wen-hsiung $\mathrm{Ko}^{* *}$ and Wang-ching $\mathrm{Ho}^{* *}$ \\ Wen-hsiung $\mathrm{Ko}^{* *}$ ・Wang-ching Ho**: Rhizoctonia solani および \\ Pythium splendens に対する土培の抑止作用の検索*
}

\begin{abstract}
Growth of mycelia and germination of sporangia amended with root extract on soil surface were used to detect soils suppressive to Rhizoctonia solani and Pythium splendens, respectively. In tests with 30 soil samples collected from various locations in Hawaii, 5 inhibited growth of $R$. solani more than $50 \%$ and 8 inhibited sporangial germination of $P$. splendens more than $50 \%$ as compared with conducive soil. Three of the soils were suppressive to both $R$. solani and $P$. splendens. Steaming the soil for $10-15 \mathrm{~min}$ at $97-98 \mathrm{C}$ eliminated suppressiveness as evidenced by no reduction of either mycelial growth of $R$. solani or sporangial germination of $P$. splendens. Steam treatment reduced populations of fungi, actinomycetes, and bacteria in suppressive soils to approximately $0.04 \%, 1 \%$ and $5 \%$, respectively, of the original numbers. Propylene oxide treatment and autoclaving increased inhibition on some soils. Similar effects were not found on steam-treated soils. The results indicate that suppressive soils may exist in small islands in a field and that the degree of suppressivenss variees from location to location.
\end{abstract}

(Received May 10, 1982)

Key Words: Suppressive soil, Rhizoctonia solani, Pythium splendens.

\section{Introduction}

Suppressive soils occurring naturally in fields are usually recognized by consistent observation of lower incidence of disease in a certain area in comparison with that in the nearby area ${ }^{1,3,7)}$. The suppressive fields involved are relatively large and the number of such suppressive soils which have been reported so far is very limited. Since both microorganisms and nonbiological components in soils are very diverse and their distribution is not uniform ${ }^{2,5)}$, it is considered possible that suppressive soil may exist as islands, small in area, in proportion to the total area of a conducive field. Two different methods were, therefore, used to detect suppressivenss in such small areas. A brief account of this work has been published ${ }^{14)}$.

* This research was supported in part by a grant under the U.S. D. A. Section 406 Program. Journal Series Paper No. 2652 of the Hawaii Institute of Tropical Agriculture and Human Resources.

** Department of Plant Pathology, University of Hawaii, Beaumont Agricultural Research Center, Hilo, Hawaii 96720, U.S.A. Present address of the junior author: Taiwan Seed Service, Shinshieh, Taichung, Taiwan. 


\section{Materials and Methods}

Soils. Soil samples collected from forests, pastures and vegetable farms on the island of Hawaii were taken from a depth of 0 to $10 \mathrm{~cm}$ after the surface litter was cleared. Each sample about 2 to $3 \mathrm{~kg}$ was a composite of five subsamples taken within a circle of approximately $2 \mathrm{~m}$ diam. Unless otherwise stated one sample was collected from one location which represented a different vegetation, soil type or elevation. Soils were sifted, moistened to about $65 \%$ field capacity and stored at $24 \mathrm{C}$ in loosely closed glass jars for at least 1 mo to let microorganisms exhaust nutrients which may become available due to soil disturbance ${ }^{17)}$. For measurement of the growth of Rhizoctonia solani Kühn on the surface of soil, approximately $50 \mathrm{~g}$ of soil adjusted to about $75 \%$ field capacity was placed in a Petri dish ( $150 \mathrm{~mm}$ diam, $25 \mathrm{~mm}$ high), compressed to a block measuring about $130 \times 40 \times 8 \mathrm{~mm}$, and the surface was smoothened. For measurement of germination of Pythium splendens Braun sporangia on soil surface, approximately $8 \mathrm{~g}$ of soil was similarly prepared on a glass slide to give a block of soil measuring about $50 \times 25 \times 3 \mathrm{~mm}$. Silt loam ( $\mathrm{pH}$ 5.4) collected from Lalamilo Experimental Farm was used as a conducive control soil because it did not restrict mycelial growth of $R$. solani nor did it inhibit germination of $P$. splendens sporangia amended with root extract.

Growth of R. solani mycelia on soil. R. solani (R-434) obtained from M. Aragaki was maintained on $10 \% \mathrm{~V}-8$ agar $\left(10 \% \mathrm{~V}-8\right.$ juice, $0.02 \% \mathrm{CaCO}_{3}, 2 \%$ Bacto agar). A $5 \mathrm{~mm}$ plug of inoculum was placed on the center of a V-8 agar plate and 20 to 30 sterilized discs $(6 \mathrm{~mm}$ diam) of polycarbonate membrane (CPR, $0.2 \mu \mathrm{m}$; Nuclepore Corporation, Pleasanton, California) were placed around the inoculum. After incubation at $24 \mathrm{C}$ for 3 days, a membrane disc containing mycelia was detached from the plate with a surgical blade and placed at one end of a soil block in the Petri plate. All plates were then placed in a large polyethylene bag and incubated at 24 C. Growth of $R$. solani was observed directly on soil surfaces every two days for 6 days using a Bausch \& Lomb stereomicroscope at the magnification of $7.5^{12}$.

Germination of $\boldsymbol{P}$. splendens sporangia on soil. Sporangia of $P$. splendens were suspended in root extract of cucumber to overcome the general fungistasis of soil ${ }^{17)}$. Cucumber was selected because it is very susceptible to the test organisms and easy to obtain large quantities of roots. For production of sporangia, P. splendens $(106 \mathrm{~F})$ isolated from cucumber was grown in $25 \mathrm{ml}$ of $10 \% \mathrm{~V}-8$ broth $(10 \% \mathrm{~V}-8$ juice, $0.02 \% \mathrm{CaCO}_{3}$ ) in a $250 \mathrm{ml}$ flask for 7 days at $24 \mathrm{C}$. Mycelia were washed two times with distilled water, and triturated in $25 \mathrm{ml}$ distilled water with an Omni mixer at $5,000 \mathrm{rpm}$ for $2 \mathrm{~min}$. The resulting suspension was passed through a $53 \mu \mathrm{m}$ screen. Sporangia in the filtrate were concentrated by centrifugation at $5,000 \mathrm{rpm}$ for $10 \mathrm{~min}$ and adjusted to $2 \times 10^{5}$ sporangia per $\mathrm{ml}$ with a Pipetman digital microliter pipet ( $\mathrm{P}$ 20D; West Coast Scientific, Inc., Oakland, California) ${ }^{13)}$.

About 100 cucumber seeds in a $250 \mathrm{ml}$ beaker were washed overnight with water dripping from a faucet, and spread in a $1000 \mathrm{ml}$ beaker covered with wet cheesecloth kept moist by twice daily atomization. The beaker with seeds was placed horizontally in darkness at $24 \mathrm{C}$. After 3 to 4 days, seedling roots were excised and ground in water at the ratio of $1: 9(\mathrm{w} / \mathrm{v})$ with a mortar and pestle. Extracts from these roots 
were obtained by filtering the ground material through two layers of cheesecloth. The conidial suspension was mixed with an equal volume of root extract and one drop (ca. $0.05 \mathrm{ml}$ ) of the resulting suspension was added to the surface of soil block on the glass slide which was then placed on moistened paper towels on a laboratory tray enclosed in a polyethylene bag and incubated at $24 \mathrm{C}$. After incubation for $6 \mathrm{hr}$, conidia were stained with rose bengal ( $1 \%$ rose bengal, $5 \%$ phenol, and $0.01 \% \mathrm{CaCl}_{2}$ ) and germination was counted directly on the surface of the soil using a Zeiss Universal Microscope equipped with a Model II C vertical illuminator at the magnification of $200^{12)}$.

For measurement of both mycelial growth and sporangial germination two replicates were used for each treatment and all the experiments were repeated at least once.

Soil treatments. Soil blocks on slides or petri plates were steamed in a steamer for $15 \mathrm{~min}$. The air temperature in the steamer was maintained at 97-98 C. Mycelia of $R$. solani and sporangia of $P$. splendens were placed on the soil surface after the soils were cooled. To determine the effect of steam treatment of soil on microbial populations, soil suspensions were prepared by suspending $10 \mathrm{~g}$ of steamed soil with $90 \mathrm{ml}$ of sterile distilled water in an Omni mixer at 4,500 rpm for $1 \mathrm{~min}$. Dilutions of $10^{-1}, 10^{-2}$ and $10^{-3}$ were prepared for fungi; and $10^{-2}, 10^{-3}$ and $10^{-4}$ for bacteria and actinomycetes before plating on agar media. Suspensions of non-steamed soil were diluted to $10^{-2}, 10^{-3}$ and $10^{-4}$ for fungi $; 10^{-4}, 10^{-5}$ and $10^{-6}$ for actinomycetes ; and $10^{-5}$, $10^{-6}$ and $10^{-7}$ for bacteria. Surfactant $-\mathrm{PDA}^{19)}$, alkaline water agar ${ }^{10)}$ and $\mathrm{PCNB}-$ soil extract agar ${ }^{6)}$ were used for determining the populations of fungi, actinomycetes and bacteria, respectively. Plates were incubated at $24 \mathrm{C}$ and colony numbers were determined after 7 days for bacteria and fungi, and 14 days for actinomycetes. Three plates were used for each dilution and the experiments were repeated once. For gas treatment, soil blocks on slide or petri plates were placed in a desiccator $(160 \mathrm{~mm}$ diam, $255 \mathrm{~mm}$ high) and into it $3 \mathrm{ml}$ of propylene oxide was added ${ }^{9}$. After exposure to the gas overnight, soils were allowed to aerate for $24 \mathrm{hr}$ to let the gas disperse before use.

\section{Results}

Linear growth of $R$. solani on 30 soil samples tested ranged from 10 to $130 \mathrm{~mm}$ in 6 days (Table 1). During the same period, the fungus grew $98 \mathrm{~mm}$ on conducive control soil. Soil samples No.9, 13, 16, 20 and 24 were considered suppressive because they restricted linear growth to less than $50 \%$ of that found on the conducive control. Hyphae of $R$. solani ceased to grow within 4 days on these soils. In general, fewer hyphae grew from the inoculum discs on suppressive soil than on conducive soil. Only 1 or 2 hyphae of $R$. solani were observed after 6 days on 3 suppressive soils, while 5 to 10 hyphae were observed on 12 conducive soils. Germination of $P$. splendens sporangia amended with root extract ranged from 4 to $98 \%$ on the same 30 soil samples tested (Table 1). On conducive control soil the fungus germinated $95 \%$ with root extract and $6 \%$ without root extract. Soil samples No. 1, 7, 13, 15, 16, 21, 24 and 27 were considered suppressive because germination on these soils were less than $50 \%$ of that on conducive control soil. Two of the 10 suppressive soils were suppressive 
Table 1. Growth of Rhizoctoria solani and germination of Pythium splendens sporangia coated with root extract on soils collected from various locations on the island of Hawaii

\begin{tabular}{|c|c|c|c|}
\hline \multirow[b]{2}{*}{ Soil sample designation } & \multicolumn{2}{|c|}{ R. solani } & \multirow{2}{*}{$\begin{array}{c}P . \text { splendens } \\
(\% \text { germination })\end{array}$} \\
\hline & $\begin{array}{l}\text { Linear growth } \\
(\mathrm{mm} / 6 \text { days })\end{array}$ & $\begin{array}{c}\text { Mycelium } \\
\text { density }\end{array}$ & \\
\hline 1 & $120^{\mathrm{a})}$ & $+{ }^{b)}$ & $33^{a)}$ \\
\hline 2 & 58 & + & 90 \\
\hline 3 & 90 & $H$ & 76 \\
\hline 4 & 130 & + & 88 \\
\hline 5 & 75 & $H$ & 78 \\
\hline 6 & 120 & $H$ & 88 \\
\hline 7 & 55 & \pm & 44 \\
\hline 8 & 69 & \pm & 92 \\
\hline 9 & 34 & \pm & 80 \\
\hline 10 & 75 & + & 89 \\
\hline 11 & 75 & $H$ & 84 \\
\hline 12 & 120 & $H$ & 90 \\
\hline 13 & 10 & + & 4 \\
\hline 14 & 100 & $H$ & 90 \\
\hline 15 & 60 & + & 42 \\
\hline 16 & 30 & \pm & 4 \\
\hline 17 & 50 & + & 98 \\
\hline 18 & 85 & $H$ & 88 \\
\hline 19 & 120 & H & 98 \\
\hline 20 & 25 & + & 88 \\
\hline 21 & 55 & + & 32 \\
\hline 22 & 78 & + & 90 \\
\hline 23 & 100 & + & 98 \\
\hline 24 & 12 & \pm & 8 \\
\hline 25 & 86 & + & 94 \\
\hline 26 & 70 & + & 84 \\
\hline 27 & 55 & + & 32 \\
\hline 28 & 65 & H & 84 \\
\hline 29 & 75 & $H$ & 82 \\
\hline 30 & 98 & $H$ & 56 \\
\hline Control & 98 & $H$ & 95 \\
\hline
\end{tabular}

a) Two replicates were used and the experiments were repeated once.

b) Density rating scale: \pm , only 1 or 2 hyphae from the inoculum and showing lysis on 4 th day. + , with 3 or 4 hyphae; H, with 5 to 10 hyphae barely visible with naked eye.

only to $R$. solani and five were suppressive only to $P$. splendens; whereas, the other three were suppressive to both pathogens.

Five soil samples were collected from a 3-acre area of uniform soil texture at Lalamilo Experimental Farm. It is a silt loam and the area has been used for growing Chinese cabbage. One sample was found to be suppressive to $R$. solani $(21 \mathrm{~mm} / 6$ days) and the other four were conducive $(83-123 \mathrm{~mm} / 6$ days). Germination of $P$. 
splendens sporangia on one of the same five soil samples was only $40 \%$, while 82 to $97 \%$ germination on the other four. In other experiments 12 soil samples were randomly collected at least $5 \mathrm{~m}$ apart from within one-acre area of pasture at South Kohala. The soil is a very fine sandy loam. Nine out of 12 samples were conducive to $R$. solani supporting $65-130 \mathrm{~mm}$ mycelial growth in 6 days, whereas the other three were suppressive with growth limited to only $2-33 \mathrm{~mm}$ in 6 days. However, all 12 samples were to a certain degree suppressive to $P$. splendens resulting in only $12-54 \%$ sporangial germination as compared to $97 \%$ on conducive control soil.

Suppressive soils No. 9 and 21 were steamed for 5, 10, 15, 30 and 60 min, cooled, and tested for effect on growth of $R$. solani and germination of $P$. splendens sporangia, respectively, as described previously. Maximum growth of $R$. solani and germination of $P$. splendens sporangia on suppressive soil occurred on soil steamed for 10 and 15 min, respectively (Fig. 1). Steam treatment for $15 \mathrm{~min}$ was, therefore, selected for further study. The population study revealed that steam treatment for $15 \mathrm{~min}$ eliminated about $93-99 \%$ of the total microbial populations in soils (Table 2). In all three soils tested fungi were most sensitive to steam treatment, followed by actinomycetes and bacteria. The populations of fungi, actinomycetes, and bacteria were reduced to about $0.04 \%, 1 \%$ and $5 \%$, respectively, of the original numbers.

Increased linear growth of $R$. solani was observed on all five suppressive soils after they were steamed for $15 \mathrm{~min}$. The same treatment did not result in an effect on linear growth on the conducive control soil (Table 3 ). Density of $R$. solani mycelium on suppressive and conducive soils increased after steam treatment. Increased germination of $P$. splendens sporangia was also observed on 6 of 8 steamed suppressive soils (Table 4). However, germination on soil samples No. 13 and 24, and the conducive

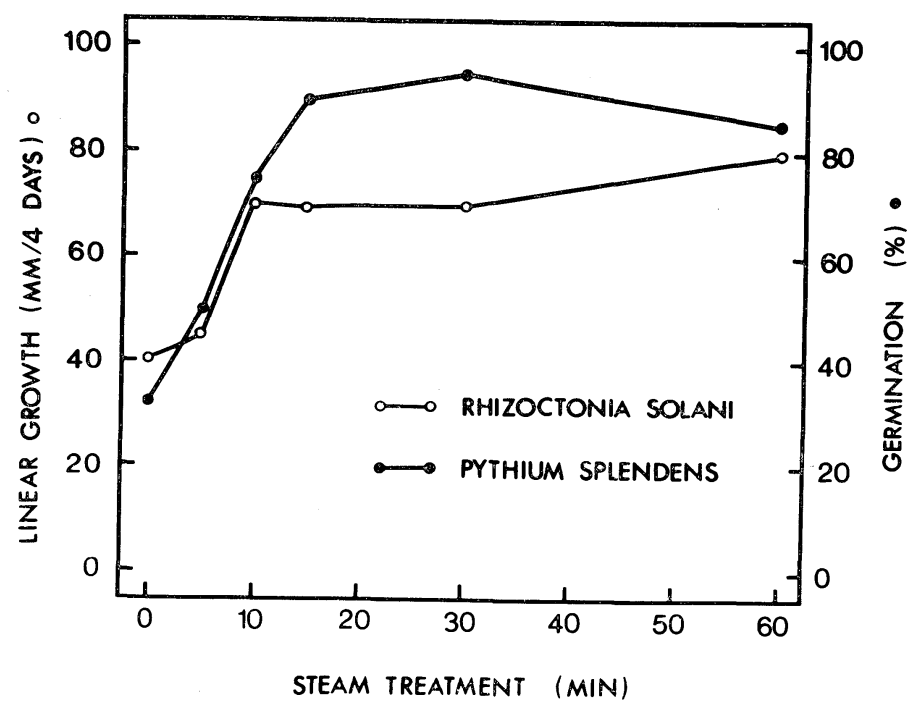

Fig. 1. Linear growth of Rhizoctonia solani and germination of Pythium splendens sporangia amended with root extract on suppressive soils steamed at 97-98C for various time intervals. Suppressive soils used were No. 9 for $R$. solani and No. 21 for $P$. splendens. 
Table 2. Numbers of microorganisms in suppressive soils before and after steaming at $97-98 \mathrm{C}$ for $15 \mathrm{~min}$

\begin{tabular}{|c|c|c|c|c|c|c|}
\hline \multirow{2}{*}{ Soil sample } & \multicolumn{2}{|c|}{ Fungi } & \multicolumn{2}{|c|}{ Actinomycetes } & \multicolumn{2}{|c|}{ Bacteria } \\
\hline & Natural & Steamed & Natural & Steamed & Natural & Steamed \\
\hline 13 & $3 \times 10^{5^{a)}}$ & 240 & $131 \times 10^{5}$ & $2.0 \times 10^{5}$ & $123 \times 10^{5}$ & $17 \times 10^{5}$ \\
\hline 16 & $5 \times 10^{5}$ & 75 & $78 \times 10^{5}$ & $0.9 \times 10^{5}$ & $126 \times 10^{5}$ & $4 \times 10^{5}$ \\
\hline 24 & $2 \times 10^{5}$ & 84 & $212 \times 10^{5}$ & $0.2 \times 10^{5}$ & $177 \times 10^{5}$ & $1 \times 10$ \\
\hline
\end{tabular}

a) No. propagules/g dry soil. Three dilutions of soil suspension were used for each group of microorganisms for each soil sample, and three plates were used for each dilution. Data were from one of two experiments with similar results.

Table 3. Effect of steam treatment on suppressiveness of soils as measured by growth of Rhizoctonia solani

\begin{tabular}{ccccc}
\hline \multirow{2}{*}{ Soil sample } & \multicolumn{4}{c}{ Soil treatment } \\
\cline { 2 - 5 } & Steaming & None & Steaming & None \\
\hline 9 & $73 \mathrm{~A}^{\mathrm{a})}$ & $32 \mathrm{~B}$ & W $^{\mathrm{b}}$ & + \\
13 & $30 \mathrm{~A}$ & $10 \mathrm{~B}$ & + & + \\
16 & $43 \mathrm{~A}$ & $24 \mathrm{~B}$ & + & + \\
20 & $44 \mathrm{~A}$ & $25 \mathrm{~B}$ & + & + \\
24 & $35 \mathrm{~A}$ & $22 \mathrm{~B}$ & + & + \\
\hline
\end{tabular}

a) Linear growrh ( $\mathrm{mm} / 4$ days). Values followed by the same letter for each soil sample were not significantly different at $\mathrm{P}=0.05$.

b) Density of mycelial growth. Rating scale: \pm , only 1 or 2 hyphae from the inoculum and showing lysis on 4 th day; +, with 3 or 4 hyphae; H, with 5 to 10 hyphae barely visible with naked eye; $H$, with more than 10 hyphae visible with naked eye.

Table 4. Effect of steam treatment on suppressiveness of soils as measured by germination of Pythium splendens sporangia amended with root extract

\begin{tabular}{ccr}
\hline \multirow{2}{*}{ Soil sample } & \multicolumn{2}{c}{ Soil treatment } \\
\cline { 2 - 3 } & Steaming & \multicolumn{1}{c}{ None } \\
\hline 1 & $76 \mathrm{~A}^{\mathrm{a}}$ & $33 \mathrm{~B}$ \\
7 & $82 \mathrm{~A}$ & $41 \mathrm{~B}$ \\
13 & $3 \mathrm{~A}$ & $4 \mathrm{~A}$ \\
15 & $83 \mathrm{~A}$ & $46 \mathrm{~B}$ \\
16 & $96 \mathrm{~A}$ & $8 \mathrm{~B}$ \\
21 & $92 \mathrm{~A}$ & $25 \mathrm{~B}$ \\
24 & $13 \mathrm{~A}$ & $4 \mathrm{~A}$ \\
27 & $81 \mathrm{~A}$ & $31 \mathrm{~B}$ \\
Conducive soil & $96 \mathrm{~A}$ & $95 \mathrm{~A}$ \\
\hline
\end{tabular}

a) Germination, \%. Values followed by the same letter for each soil sample were not significantly different at $\mathrm{P}=0.05$. control soil was not significantly increased as a result of steam treatment.

Suppressive soils were steamed for $15 \mathrm{~min}$, exposed to propylene oxide vapor overnight or autoclaved for $15 \mathrm{~min}$ to partially or completely eliminate soil microorganisms. Because the amount of some suppressive soils left was not enough for these tests, different suppressive soils obtained during the latter screenings were also used. Similar to steam treatment, autoclaving also resulted in increased linear growth of $R$. solani on all the suppressive soils tested (Table 5). However, propylene oxide treatment not only failed to increase growth of $R$. solani on two of the suppressive soils, but decreased the growth on conducive 
Table 5. Effect of steaming, autoclaving and propylene oxide treatment on growth of Rhizoctonia solani on suppressive soils

\begin{tabular}{cccrc}
\hline \hline \multirow{2}{*}{ Soil sample } & \multicolumn{5}{c}{ Soil treatment } \\
\cline { 2 - 5 } & Steaming & Autoclaving & Propylene oxide & None \\
\hline 13 & $20.5 \mathrm{~A}^{\mathrm{a}}$ & $24.3 \mathrm{~A}$ & $12.5 \mathrm{~B}$ & $5.5 \mathrm{C}$ \\
20 & $46.8 \mathrm{~A}$ & $47.8 \mathrm{~A}$ & $18.5 \mathrm{~B}$ & $20.0 \mathrm{~B}$ \\
79 & $47.3 \mathrm{~A}$ & $30.8 \mathrm{~B}$ & $19.0 \mathrm{C}$ & $15.5 \mathrm{C}$ \\
90 & $50.0 \mathrm{~B}$ & $62.3 \mathrm{~A}$ & $35.0 \mathrm{C}$ & $20.5 \mathrm{C}$ \\
94 & $31.0 \mathrm{~B}$ & $31.5 \mathrm{~B}$ & $44.5 \mathrm{~A}$ & $51.0 \mathrm{~B}$ \\
\hline
\end{tabular}

a) Linear growth $(\mathrm{mm} / 4$ days). Values followed by the same letter for each soil sample were not significantly different at $\mathrm{P}=0.05$ according to Duncan's new multiple range test.

Table 6. Effect of steaming, autoclaving and propylene oxide treatment on suppressiveness of soils as measured by germination of Pythium splendens sporangia amended with root extract

\begin{tabular}{crrrr}
\hline \hline \multirow{2}{*}{ Soil sample } & \multicolumn{4}{c}{ Soil treatment } \\
\cline { 2 - 5 } & Steaming & Autoclaving & Propylene oxide & None \\
\hline 13 & $8 \mathrm{~A}^{\mathrm{a}}$ & $9 \mathrm{~A}$ & $5 \mathrm{~A}$ & $7 \mathrm{~A}$ \\
78 & $79 \mathrm{~A}$ & $53 \mathrm{~B}$ & $80 \mathrm{~A}$ & $21 \mathrm{C}$ \\
79 & $82 \mathrm{~A}$ & $28 \mathrm{C}$ & $82 \mathrm{~A}$ & $74 \mathrm{~B}$ \\
90 & $82 \mathrm{~A}$ & $83 \mathrm{~A}$ & $82 \mathrm{~A}$ & $21 \mathrm{~B}$ \\
94 & $80 \mathrm{~A}$ & $75 \mathrm{~A}$ & $71 \mathrm{~A}$ & $94 \mathrm{~A}$ \\
\hline
\end{tabular}

a) Germination, \%. Values followed by the same letter for each soil sample were not significantly different at $\mathrm{P}=0.05$ according to Duncan's new multiple range test.

control soil. Germination of P. splendens sporangia increased following autoclaving of three suppressive soils, was not affected on soil sample No.13, and was decreased on soil sample No. 79 (Table 6). Propylene oxide treatment of 4 of 5 suppressive soils resulted in increased sporangial germination, but not on soil sample No.13. Germination on conducive control soil was decreased by propylene oxide treatment.

\section{Discussion}

The results indicate that suppressive soil may exist in small islands in a field and that the degree of suppressiveness varies from location to location. About $17 \%$ of soil samples collected from various locations in Hawaii were suppressive to $R$. solani, and $27 \%$ were suppressive to $P$. splendens. The soil in a field at Lalamilo Experimental Farm was generally conducive to $R$. solani and $P$. splendens. However, one of the five soil samples collected from that area was found to be suppressive to $R$. solani or $P$. splendens. The area at South Kohala selected for this study was generally suppressive to $P$. splendens, but conducive to $R$. solani. However, 3 of the 12 soil samples collected from this area were suppressive to $R$. solani, and the soil samples inhibited sporangial germination of $P$. splendens from $44 \%$ to $88 \%$. 
Growth of mycelia of most fungi is restricted in natural soil ${ }^{17)}$. $R$. solani has been reported to be among the very few species which are not subjected to such restriction ${ }^{4,8)}$. Present results show that the distance $R$. solani travelled was greatly affected by the type of soils used. On 30 soil samples collected from various locations the range of linear growth by this fungus extended from 10 to $130 \mathrm{~mm}$ in 6 days. The fungus ceased to grow on suppressive soils within 4 days. Sporangia of $P$. splendens germinated poorly on natural soil without addition of nutrients due to the presence of general soil fungistasis ${ }^{17}$. Amending $P$. splendens sporangia with root extract before addition to the 30 soil samples mentioned above resulted in germination ranging from $4 \%$ (no annulment of fungistasis) to $98 \%$ (complete annulment). This suggests that the degree of annulment of soil fungistasis by nutrients may be affected by soil type. Gemination of Calonectria crotalariae conidia on soils was reported to be $80-89 \%$ by Hwang and $\mathrm{Ko}^{11)}$, and $28 \%$ by Roth and Griffin ${ }^{18)}$. In addition to the clonal differences as suggested by Roth and Griffin ${ }^{18)}$, according to this study soil type differences may also account for the variation of the results.

Steam treatment reduced the total microbial population to $0.3-7.4 \%$ of the originals. Therefore, the reduced inhibition in suppressive soils is probably mainly due to the destruction of soil microorganisms. However, the extent to which the increse in growth and germination was due to nutrients released from killed microorganisms is still unknown. Although microorganisms appear to be an important factor responsible for inhibiting the growth of $R$. solani on suppressive soils tested, nonbiological factors also may be involved because on some steamed suppressive soils growth of $R$. solani was not as good as that on a conducive soil (Table 3). Inhibition of P. splendens germination by soil samples No. 13 and 24 appears to be caused mainly by nonbiological factors, whereas inhibition by the other soil samples seems to be of biological origin (Table 4).

Steaming appears to be a better treatment of soil than gas treatment and autoclaving for studying the relative importance of biological and nonbiological factors in suppressing test organisms. Propylene oxide treatment reduced both linear growth of $R$. solani and germination of $P$. splendens sporangia on the conducive control soil. It is considered possible that in certain types of soils inhibitory substances may appear due to propylene oxide treatment, or relatively high concentration of residual propylene oxide may be retained. Germination of $P$. splendens sporangia was lower on autoclaved than on natural soil sample No. 79 (Table 6). Similar results were reported by Ko and Hora ${ }^{15)}$ who showed that the inhibitory effect of certain acid soils against germination of Neurospora tetrasperma ascospores was enhanced by autoclaving. Enhanced inhibition by steam treatment was not observed in any of the soils tested.

It is considered possible that the principles involved in the inhibition of mycelial growth of $R$. solani and sporangial germination of $P$. splendens in these soils may be applicable to controlling diseases caused by these two pathogens. Control of dampingoff of beets caused by $R$. solani by means of PCNB has been shown to be due to the suppression of growth of this pathogen in soil ${ }^{16)}$. When one of the suppressive soils obtained in this study was infested with $P$. splendens sporangia and planted with cucumber seeds, more than $90 \%$ of the seedlings survived after two weeks. However, during the same period, more than $90 \%$ of the seedlings were killed in conducive 
control soil inoculated with the same amount of $P$. splendens sporangia (C. W. Kao and W. H. Ko, unpublished).

\section{Literature cited}

1. Alabouvette, C., Rouxel, F. and Louvet, J. (1979). In Soil-Borne Plant Diseases (Schippers, B. and Gams, W. eds.). Academic Press, London. pp. 165-182.

2. Alexander, M. (1977). Introduction to Soil Microbiology. John Wiley \& Sons, New York. pp. 467.

3. Baker, K. F. and Cook, R. J. (1974). Biological Control of Plant Pathogens. W. H. Freeman and Co., San Francisco. pp. 433.

4. Blair, I. D. (1943). Ann. Appl. Biol. 30 : 118-127.

5. Brady, N. C. (1974). The Nature and Properties of Soils. Macmillan Publishing Co., New York. pp. 639.

6. Farley, J. D. and Lockwood, J. L. (1968). Phytopathology 58: 714-715.

7. Furuya, H., Owada, M. and Ui, T. (1979). Ann. Phytopathol. Soc. Japan 45: 608-617.

8. Garrett, S. D. (1970). Pathogenic Root-Infecting Fungi. Cambridge University Press, London. pp. 294.

9. Hansen, H. N. and Snyder, W.C. (1947). Phytopathology 37: 369-391.

10. Ho, W. C. and Ko, W. H. (1980). Ann. Phytopathol. Soc. Japan 46: 634-638.

11. Hwang, S. C. and Ko, W. H. (1974). Mycologia $66: 1053-1055$.

12. Ko, W. H. (1971). Phytopathology 61: 437-438.

13. Ko, W. H., Chase, L. L. and Kunimoto, R. K. (1973). Ibid. 63: 1206-1207.

14. Ko, W. H. and Ho. W.C. (1981). Ibid. $71: 886$ (Abstr.).

15. Ko, W. H. and Hora, F. K. (1971). Soil Sci. 112: 276-279.

16. Ko. W. H. and Oda, M. K. (1972). Phytopathology $62: 385-387$.

17. Lockwood, J. L. (1977). Biol. Rev. 52: 1-43.

18. Roth. D. A. and Griffin, G. J. (1980). Soil Biol. Biochem. 12: 531-536.

19. Steiner, G. W. and Watson, R. D. (1965). Phytopathology 55: 728-730.

\section{和文 摘要}

\section{Phizoctonia solani および Pythiun splendens に} 対する土塞の抑止作用の検索

Ko, W. H. • Ho, W. C.

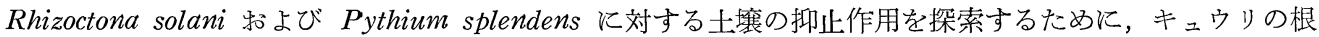

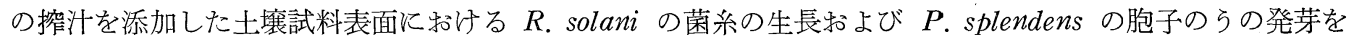
観察した。八ワイ島の各地で採集した 30 コの土壤試料を用いて実験を行ったが，そのうち 5 בは R. solani の菌采の生育を $50 \%$ 抑制し，8 コは $P$. splendens の胞子のらの発芽を50\%抑制した。また 3 二は両菌に対 して抑制的に作用した。土㙥を $97 \sim 98 \mathrm{C}$ の蒸気で $10 \sim 15$ 分間処理すると，抑止作用は消失し， R. solani の 菌系生育の抑制拈よび P. splendens の発芽抑制がみられなくなる。蒸気処理により, 菌類, 放線菌拈よび 細菌数はそれぞれ約 $0.04 \% ， 1 \%$ 怙よび $5 \%$ に減少する。土壤試料によっては，ポリプレンオキサイドでく 几蒸あるいは高圧蒸気殺菌をすると抑制が増加する例があった。しかしこの様な効果は上記の蒸気処理によ っては認められなかった。抑止土䁃は國場のなかに点在し，抑止作用の程度は場所によって異なる。 